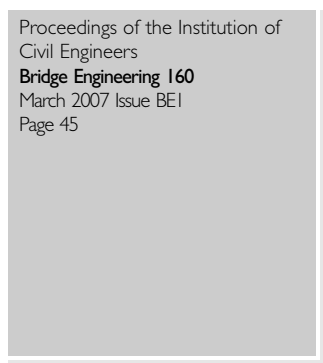

\title{
Bridge Engineering: Referees for 2006
}

The following is a list of referees who have reviewed papers for Bridge Engineering between 1 January 2006 and 31 December 2006. The Institution of Civil Engineers is very grateful for their assistance.

We are continually looking for suitable reviewers for papers submitted to Bridge Engineering. Papers published in the Proceedings of the ICE must be submitted to at least two independent referees to judge accuracy, style, impact, importance and interest.

If you are interested in reviewing articles on any topic related to bridge engineering, please submit your name, qualifications or CV, and areas of expertise. We are in need of individuals who will agree to review papers in a timely fashion (within 3 to 4 weeks of receipt) and provide confidential feedback to the Editorial Advisory Panel concerning the quality of the paper and any suggested revisions that would be appropriate.

If you are such a person, please contact Agnes Alvite (tel.: 0207665 2204; e-mail: agnes.alvite@ice.org.uk) for more information on the referee process.
A. Ahern
R. P. Johnson
B. I. G. Barr
R. J. Lark
C. J. Burgoyne
E. Larsen
M. K. Chryssanthopoulos
I. MacLeod
M. S. Chubb
B. R. Mawson
C. P. E. Cocksedge
J. McCafferty
R. S. Cooke
C. McKenna
B. Crossley
S. Metheringham
M. Cullen
T. O'Donnell
AIF Daly
A. P. Darby
T. Oakhill
R. Dixon
A. Oliver
D. K. Doran
J. Parsons
J. Evans
T. M. Roberts
M. Gilbert
R. Rocke
D. Searle
A. Hamilton
N. E. Shanmugam
A. M. Horr
M. T. Sharman
G. Hughes
J. C. Sreeves
T. J. Ibell
P. A. Jackson
J. D. Symonds
G. Waley
T. Jefferson
R. Woodward 